\section{ABOUT MIKHAIL S. GREENBERG}

Tatiana F. Yashchuk

Dostoevsky Omsk State University, Omsk, Russia Article info

Received - 2018 April 10

Accepted - 2018 May 20

Available online - 2018 August 20

\section{Keywords}

Greenberg, production risk, reasonable risk, technical crimes, Omsk State University, Leningrad State University
The introductory article of the issue - the obituary - is devoted to the outstanding Soviet and Russian lawyer - professor Mikhail S. Greenberg. The author dwells on the main mile-stones of M.S. Greenberg's scientific biography: from studying at Leningrad State University to conferring the title "Honoured Lawyer of the Russian Federation" during his work in Omsk State University, highlights the main provisions of his scientific works, characterizes the personal qualities of M.S. Greenberg. 


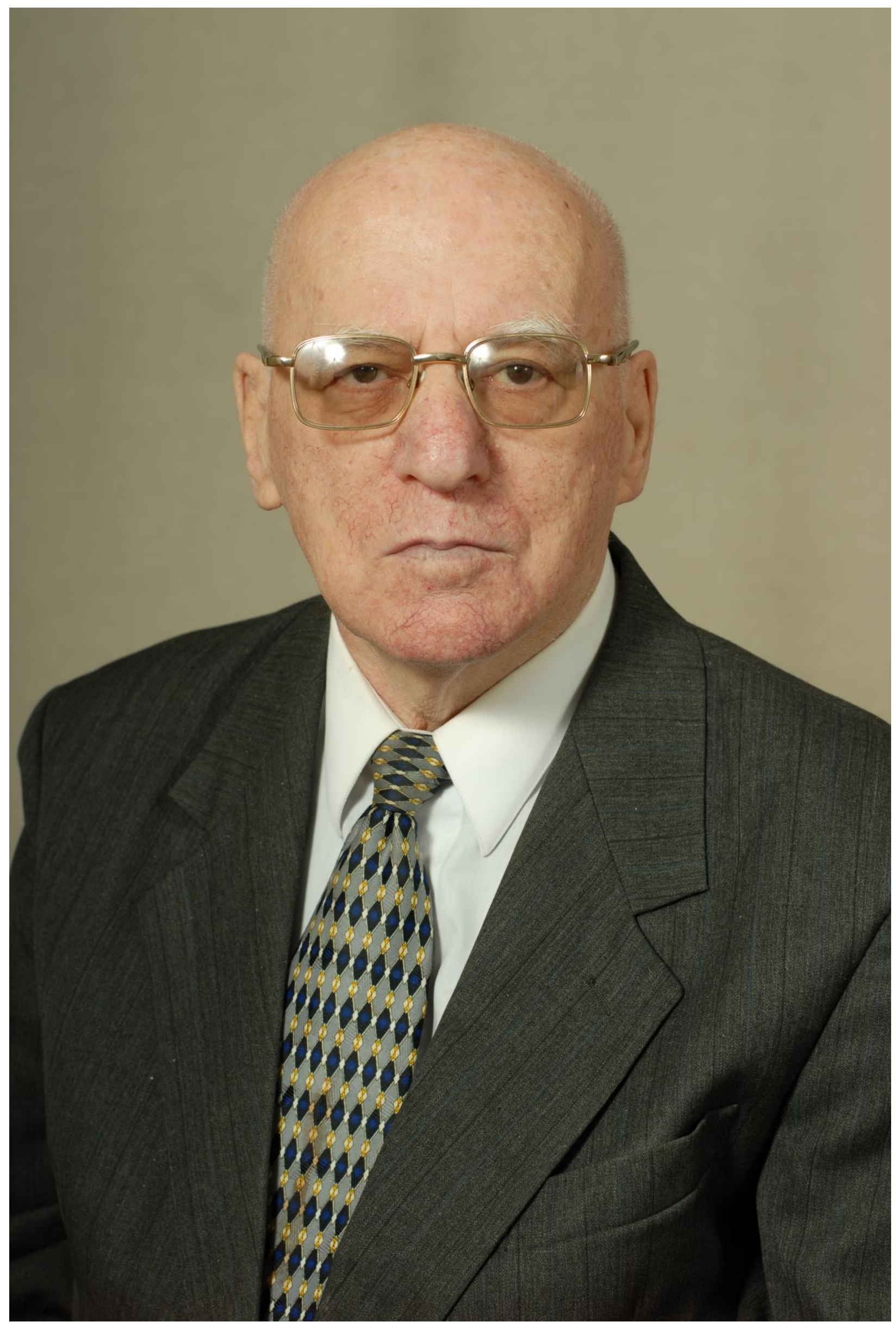


On January 25, 2018, a prominent Russian scientist, Doctor of Law, Professor, Honored Lawyer of the Russian Federation Mikhail Semenovich Grinberg, a long-time head of the Department of Criminal Law and Process of the Law Faculty of Omsk State University, F.M. Dostoevsky died. Born in the "cultural capital" of Russia - Leningrad, - he absorbed and preserved the best features of the Russian intellectual: high education, scientific conscientiousness, exceptional decency, tact and modesty.

\section{Military years.}

The generation, to which Mikhail Semenovich belonged, fell severely. His youth fell on the years of the Great Patriotic War. 18-year-old boy, like many peers, he went to the front. It was necessary to fight in different directions (North-Western, Baltic, Leningrad, Far Eastern fronts) to defend Leningrad, to liberate the Far East from the Japanese invaders. It was here, on the Far Eastern borders of the country, that the Great Patriotic War ended for a young lieutenant. As a testimony of military youth, wound was left, and as a recognition of military merit and courage, military awards, among them the Order of the Great Patriotic War of the 1st degree, the medal "For Courage".

\section{Education.}

After the Victory - return to Leningrad and admission to the Faculty of Law of Leningrad University. The war determined the composition of the students: along with yesterday's schoolchildren, university students were recently filled with army soldiers mobilized from the army. Postwar years represented a unique period in the history of this oldest national educational institution. Behind them remained a blockade, a hasty evacuation from the besieged city, when many teachers and students left on foot on the ice of Lake Ladoga. But it was during the war that the university restored the law faculty, which was removed from the structure of this university by the reformers of Soviet education in the early 1930s. The dean of the faculty was the most famous Soviet civilian scientist A.V. Venediktov. Although at this time a whole galaxy of outstanding theoreticians, state scholars, the interests of the student of Greenberg worked at the faculty in a different direction. Teacher, scientific mentor for him was Professor M.D. Shargorodsky, who embodied the best qualities of a scientist, worthy continuer of the traditions of the St. Petersburg law school. M.S. Greenberg recalled that M.D. Shargorodsky was endowed with unlimited erudition, possessed several foreign languages, and read lectures very well. The power of influence and charm of such an outstanding personality played an important role in determining the scientific preferences of MS. Greenberg. The criminal law was surrounded in the view of the beginning researcher with a halo of romance, attracted by its conflict. Mikhail Semenovich said that he wanted to take part in overcoming criminality, although it was not possible to overcome it.

3. The beginning of scientific activity.

After successful graduation from the university for 10 years, he worked as a lawyer in the Murmansk region, and in his practice met with many unusual cases, when considering which there were no usual and standard solutions.

Once Mikhail Semenovich had the opportunity to protect the locomotive driver who allowed the production risk. Although the notion of industrial and economic risk was introduced into Soviet legislation as far back as 1929, the criminal law did not contain rules that allowed legitimate risk and considered a justified risk as a condition eliminating criminal liability. Judicial practice, including that reflected in the decisions of the Plenum and the definitions of the collegia of the Supreme Court of the USSR, was controversial. The difficulties did not stop the young lawyer. On the contrary, he did not limit himself to a formal attitude, but deeply realized the importance and urgency of the problem, especially in the conditions of rapidly developing scientific progress, and began to seriously develop it. A bold, innovative approach was initially not supported even by well-known experts in criminal law. M.D. Shargorodsky warned his pupil that, with all the attractiveness of the topic, it would be very 
difficult to defend the thesis. His fears were not in vain. The positions put up for defense were severely criticized, and at the meeting of the joint council the thesis, as Mikhail Semenovich recalled, was failed. Then successful defense took place, but the novelty of the research approach, the proposals put forward to improve the criminal legislation, were taken very carefully by the scientific community, and almost two years the thesis was not awarded the degree of candidate of legal sciences. The validity of the provisions of MS. Life itself confirmed life in Greenberg. Issued in 1963, the book "The problem of production risk in criminal law" aroused great interest and despite a large circulation for that time (10 thousand copies) quickly became a bibliographic rarity.

4. The development of a scientific career.

Over time, the topic has not simply lost its relevance, but its relevance has only increased. In 1976, M.S. Grinberg defended his doctoral dissertation "Crimes Against Public Security in the Sphere of Human-Technological Cooperation." Two monographs, several scientific articles in the journals "The Soviet State and Law" and "Jurisprudence" were published on this issue. The concept of "justified risk" formulated by him is fully reflected in Russian legislation. It is included in art. 41 of the Criminal Code of the Russian Federation, is used in the criminal laws of the countries of near and far abroad. Constructions "complicity in an imprudent crime", "technical crime" have firmly entered into the criminal law and the criminal-right doctrine. Having become acquainted with the book "Problems of Industrial Risk", kindly provided by Mikhail Semenovich, being completely far from the subject, I want to share my impressions. It is impossible not to admire the clear and clear thought of the scientist, the flawless logic of research, the deep penetration into the essence of the stated problem, the detailed knowledge of practice. The book is written in a beautiful style, beautiful Russian language, which clearly differs from the works of many contemporary authors, when the reader has to literally wade through the fence of references to laws (names, articles, parts), to discover the literal reproduction of the texts of normative acts, and behind all this, clerical language, the author's idea is not at all detected or lost. The uniqueness of the copy of the monograph kept by Mikhail Semenovich was clearly revealed. It is rather not a book taken off the shelf, but a roughing material, the work with which has continued. Numerous notes on the fields, pasted sheets, new entries - all this reflects the style of scientific creativity of M.S. Greenberg. In the 1990s, the field of scientific interests of M.S. Grinberg enriched with new problems associated with the deformation of Soviet criminal law in the 1930s, the policy of illegal repression in the USSR. In one of the first papers on this topic, published in the journal "The State and Law", Mikhail Semenovich wrote that, paradoxically, the first victim of mass repression was the criminal law. Therefore, it is very important to understand why the mechanism created by the centuries-old culture of mankind to protect society from encroachments on the conditions of its normal existence and on the costs of this mechanism has been deformed and discredited. The view of a professional scientist on the history of Soviet criminal law was supplemented by personal impressions of the times of student youth, when a careless word, an occasional joke could cost a person a career, and sometimes life.

\section{M.S. Grinberg and Omsk State University.}

Since 1976, the labor activity of MS. Greenberg is associated with the law department of Omsk State University. He was invited to a newly organized university as a major criminal law specialist. It was he who was to create one of the main departments of a legal profile within the walls of a young university. Since the establishment of the criminal law department and process on October 15, 1976 and until 1992, he was an unchanging manager, who united a qualified team that brought up a new generation of scientists and teachers. Currently, many students of MS are working at the department. Grinberg, whose path to science began in the student circle, but continued with the defense of candidate dissertations under his leadership. M.S. Greenberg quickly became a popular personality, not only at the faculty and at the university, but also in the city. For several years, Mikhail Semenovich was conducting a television program "Difficult Letters", which had a wide spectator audience. Many remembered the qualified legal advice, sometimes just everyday advice that could be obtained from the presenter. But not only this was remembered by the old program. As her loyal fans say, many of them did not need legal assistance, and they did not particularly interest in legal issues, but "Difficult letters" were watched 
regularly. Attracted the easy manner of the presenter, a beautiful, imaginative speech, a lively, intelligent conversation, an appropriate, witty joke - all that the television of the Soviet period lacked. I think if the then fashionable ratings and nominations were made then, the program and its presenter could rightfully claim the highest places. Public lectures with which M.S. Greenberg spoke on the line of the society "Knowledge". It took a lot of civil courage to read in the 1970s and 1980s, for example, a lecture on "The causes of crime in the USSR." Greenberg refers to people who form a certain spiritual atmosphere, a style of behavior, a way of thinking, without which a center of science and culture cannot live and develop, like a university, and that ultimately determines a special university aura. For a young man, a student, meeting and meetingcommunication with a person like M.S. Grinberg, a versatile scholar, a subtle connoisseur of Russian classics, an excellent speaker of the word. M.S. Greenberg is the author of many aphorisms, long and firmly included in student folklore. In 1999, M.S. Grinberg was awarded the title of "Honored Lawyer of the Russian Federation", which is awarded for significant contribution to the development of jurisprudence. The memory of Mikhail Semenovich Grinberg will forever remain in our hearts.

\begin{tabular}{|c|c|}
\hline $\begin{array}{l}\text { Информация об авторе } \\
\text { Татьяна Федоровна Ящук - доктор } \\
\text { юридических наук, профессор, профессор } \\
\text { кафедры теории и истории государства и } \\
\text { права } \\
\text { Омский государственный университет им. } \\
\text { Ф.М. Достоевского, } \\
\text { 6440777, г.Омск, пр. Мира, } 55 \text { а, } \\
\text { e-mail: yashukomsu@ @ail.ru } \\
\text { SPIN-код: 5320-8909; AuthorID: } 490627\end{array}$ & $\begin{array}{l}\text { INFORMATION ABOUT AUTHOR } \\
\text { Tatiana F. Yashchuk - Doctor of Law, } \\
\text { Professor; Professor, Department of Theory } \\
\text { and History of State and Law } \\
\text { Dostoevsky Omsk State University } \\
\text { 55a, Mira pr., Omsk, 644077, Russia } \\
\text { e-mail: yashukomsu@mail.ru } \\
\text { SPIN-code: 5320-8909; AuthorID: } 490627\end{array}$ \\
\hline Библиографическое описание статьи & Bibliographic description \\
\hline $\begin{array}{l}\text { Ящук Т.Ф. О Михаиле Семеновиче } \\
\text { Гринберге / Т.Ф. Ящук // Правоприменение. } \\
\text { - 2018. Т. 2, № 2. - С. - - DOI }\end{array}$ & 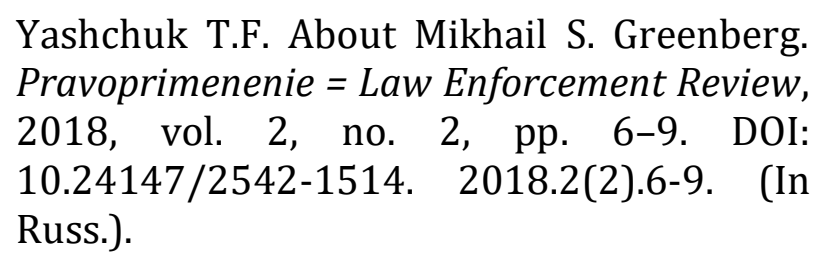 \\
\hline
\end{tabular}

